\title{
The artist and the artwork
}

When an artist produces a work he or she creates something unique a combination of the artist's imagination and a tangible way of expressing that imaginative idea. The artist also invests labour and time in the work. Just as an inventor of a new technology needs legal protection to prevent others copying and making use of his new invention, so too an artist needs legal protection to allow him or her to control the use by others of the fruits of his or her own creativity. This has never been more important than in the internet age, where reproduction, editing and distribution of images is so easy and widespread.

The argument in favour of legal protection of artistic works is that without legal protection and control over the exploitation of the work there would be less incentive for musicians, writers or artists to invest time and effort in creative work. Protection of the rights of the artist is therefore automatically provided by United Kingdom law, without the need for any formality or process, in three ways:

- Copyright law prevents the artist's work being copied or reproduced without the consent of the artist.

- Moral rights allow the artist to prevent the use or reproduction of the work in ways that the artist does not approve of.

- The artist's resale right allows the artist to be paid a percentage of the sale price of the artwork each time it is resold.

We will examine each of these in turn.

\subsection{Copyright}

Copyright is the legal protection given to artists, to protect their economic and moral rights in the artworks they produce. Copyright is 
part of a group of intellectual property rights that comprise patents, industrial designs and trademarks. These are legal rights given to the creator of a creative work over their creation.

Copyright requires no formality to be enforceable, unlike patents, registered industrial designs and trademarks, which require formal registration. Copyright protection applies automatically to any creative work that satisfies certain criteria regardless of the identity and creative credentials of the person who produced the creative work. There is no need to apply for copyright protection, register the work or even label it as being copyright.

Copyright is also a distinct right from the ownership right in a creative work. A person buying a painting at auction which is protected by copyright will become the owner of the painting but will, unless the copyright is transferred to him or her, usually need the permission of the copyright owner to make copies of the artwork. Equally, a buyer of an unreleased 'bootleg' recording of the Beatles practising in the recording studio is the owner of the recording and may listen to it, but may not broadcast or make copies of it without the permission of the copyright owner.

Copyright law in the United Kingdom and the United States has traditionally started from the economic model - the idea that an artist should be able to have continuing financial enjoyment of the benefits of his or her creation. This is achieved by giving the artist the ability, through licensing, to control acts such as copying, renting, lending, adaptation or communication to the public of his or her artwork. These economic rights of the artist can also be assigned or sold to others. This approach, which focuses on the economic value of the work, is in contrast to many European legal systems which have adopted a slightly different starting point - the fundamental moral right of the artist to prevent the treatment of the artwork in ways of which the artist does not approve. These moral 'policing' rights - originally conceived in continental Europe but now also enshrined in UK law - include the right to be identified as the author of the artwork and the right to object to derogatory treatment of the artwork. Unlike the economic model, moral rights are not assigned or licensed. They are instead vested in the artist and the artist's estate. Gradually the economic model has been diluted by the continental European approach through European legislation and case law, so that now there is considerable harmonisation across Europe in many aspects of copyright law. 
In the United Kingdom, modern copyright law is enshrined in the Copyright, Designs and Patents Act 1988 (CDPA 1998). The CDPA 1988 seeks to incorporate both the economic rights and the moral rights of the artist. Where copyright exists in an artwork, the copyright owner has the exclusive right to copy the work (s 17), issue copies of the artwork to the public ( $\mathrm{s} 18$ ) or make an adaptation of the artwork (s 21). The copyright owner is also entitled to prevent unauthorised persons doing any of these things in relation to the artwork. That right relates not just to the artwork as a whole but to any substantial part of the artwork (s 16(3)).

\subsubsection{What types of artwork are protected by copyright?}

The starting point for determining whether a creative work is protected by copyright is to look at whether it is of a kind which can be protected by copyright. CDPA 1988, s 1(1)(a) states that copyright shall subsist in 'original literary, dramatic, musical or artistic works'. Section 4 goes on to define which types of 'artistic works' are capable of being protected by copyright. These include:

(a) a graphic work, photograph, sculpture or collage, irrespective of artistic quality

(b) a work of architecture being a building or model for a building, or

(c) a work of artistic craftsmanship.

Leaving aside, for the time being, the requirement of originality and the question of artistic quality, it will be noticed that the types of artwork protected by the CDPA 1988 are wide ranging.

\subsubsection{Graphic works: paintings, drawings and engravings}

The term 'graphic work' includes (a) any painting, drawing, diagram, map, chart or plan and (b) any etching, lithograph, woodcut or similar work (s 4(2)(b)).

In determining whether a work is a painting or a drawing for the purposes of copyright law, the ordinary meaning should be given to the words painting and drawing. It is important to remember that no regard should be given to whether or not the work has artistic merit. A drawing or painting can be extremely simple and yet be protected. However, the more simple the work is, the more exact the reproduction will need to be in order to amount to an infringement of copyright. 


\subsubsection{Photographs}

A photograph for the purposes of the CDPA 1988 is defined as 'a recording of light or other radiation on any medium on which an image is produced or from which an image may by any means be produced, and which is not part of a film' (s 4(2)(b)). A photograph can therefore be a light recording captured on light sensitive film, paper or digital sensor.

\subsubsection{Sculpture}

The CDPA 1988 makes it clear that sculpture includes 'any cast or model made for the purposes of sculpture' (s $4(2)(\mathrm{b})$ ) with the result that the sculpture as well as the cast used to make it is protected. However, it does not provide any more guidance on what constitutes a sculpture for the purposes of copyright protection. That question was addressed in Lucasfilm Ltd $v$ Ainsworth, ${ }^{1}$ where the issue before the court was whether the Imperial Stormtroopers' helmets used in the Star Wars film were sculptures within the meaning of the CDPA 1988 and were therefore protected by copyright, rather than the law of registered or unregistered design which protects more utilitarian three dimensional designs. The court decided that the helmets were not 'sculptures' within the meaning of the CDPA 1988. Specifically, it held that the ordinary meaning of the term 'sculpture' should not extend to a helmet used in the making of a film, even where the helmet contributed to the artistic effect of the overall film. The court therefore considered that the helmet was utilitarian rather than a work of art, and was not protected by copyright law as a sculpture. In reaching its conclusions the court endorsed a list of guidelines to be used in determining whether a work is a sculpture within the meaning of the CDPA 1988:

(i) Some regard has to be had to the normal use of the word.

(ii) Nevertheless, the concept can be applicable to things going beyond what one would normally expect to be art in the sense of the sort of things that one would expect to find in art galleries.

(iii) It is inappropriate to stray too far from what would normally be regarded as sculpture.

(iv) No judgement is to be made about artistic worth.

(v) Not every three dimensional representation of a concept can be

1 [2011] UKSC 39. 
regarded as a sculpture. Otherwise every three dimensional construction or fabrication would be a sculpture, and that cannot be right.

(vi) It is of the essence of a sculpture that it should have, as part of its purpose, a visual appeal in the sense that it might be enjoyed for that purpose alone, whether or not it might have another purpose as well ...

(vii) The fact that the object has some other use does not necessarily disqualify it from being a sculpture, but it still has to have the intrinsic quality of being intended to be enjoyed as a visual thing ...

(viii) The process of fabrication is relevant but not determinative.

The forms of art known as readymade, objets trouvés, installations or assemblages are works where the artist will take an object or group of objects which are utilitarian or ordinary, often seeking to use them to challenge the idea of the nature of art. Examples of such art are the works of Marcel Duchamp, Tony Cragg, Pablo Picasso and Michael Landy. Such works will usually fall within the definition of sculpture for the purposes of copyright law.

\section{Example}

- Marcel Duchamp's 1917 work Fountain is an example of readymade art, where the artist conscripts an ordinary manufactured item and displays it as a work of art. In this case the item was a porcelain urinal purchased from a plumbing supplier. Duchamp arranged it lying on its back and signed it with the inscription 'R.Mutt 1917'. R stood for a French slang word for moneybags and Mutt was a nod to the company who had sold the urinal to Duchamp. Fountain is a sculpture for the purposes of copyright protection under United Kingdom copyright law because, taking account of the principles in Lucasfilm Ltd $v$ Ainsworth (see above), it has as its purpose a visual appeal and is intended to be enjoyed for that purpose alone, regardless of the fact that the urinal has another purpose as well. That purpose was a challenge to his audience to question the concept of what is or is not art.

It is also worth noting that even if an artwork is a sculpture for the purposes of copyright law, an unusual exception to copyright protection applies in the United Kingdom to sculptures and works of artistic craftsmanship which are on permanent display to the public or in premises open to the public. In the case of such work there will be no infringement by making a graphic work (such as a painting or drawing), a photograph or a film representing it (s 62). 


\subsubsection{Collages}

Collages are artworks created by assembling images. The technique became widely used as an art form by early twentieth-century artists such as Braque and Picasso, who incorporated cuttings from newspapers and magazines into their canvases to provide a contemporary context to the artworks. The technique was widely adopted and developed by artists such as Man Ray and Nancy Spero, often involving quotes, photographs and images taken from other sources and incorporated into a single artwork. A collage of these items may be a copyright work in its own right but the individual images and text from which the collage is comprised may themselves also be protected by copyright and therefore require the copyright holder's consent to be used in the collage if a substantial part of the copyright holder's work is reproduced. The question of what is substantial is often relevant because collages frequently incorporate small parts or sections of other images. As a rule of thumb the use is likely to be considered substantial if it is particularly recognisable and an integral part of the collage work. Care also needs to be taken not to infringe the copyright owner's moral rights (see section 1.2.2.2, 'The right of integrity') when using a cutdown version of the original image.

\subsubsection{Works of artistic craftsmanship}

'Works of artistic craftsmanship' is intended to cover works such as painted tiles, pottery, book bindings, wrought iron gates, cutlery, needlework and stained glass, jewellery and twentieth-century furniture. The difficulty here is to distinguish between works which are utilitarian and those which are works of art, and therefore qualify for copyright protection. The reason this has been a live issue is that the authors of design prototypes or other works of craftsmanship which might usually be protected as registered designs have sometimes sought to claim copyright protection as works of artistic craftsmanship, which can be more advantageous. However, in order to benefit from such protection, the author needs to demonstrate not only that it is a work of craftsmanship, but that it is an artistic work. The courts have sought, without success, to establish a clear test for determining whether or not a work is a work of artistic craftsmanship. The leading case on this issue is George Hensher Ltd $v$ Restawile Upholstery (Lancs) Ltd, ${ }^{2}$ which involved a dispute over the copying of prototype furniture design. The

2 [1976] AC 64. 
judges' speeches in that case sought to set out the following principles to be borne in mind:

(1) A work is artistic if it is genuinely admired by a section of the community by reason of the emotional or intellectual satisfaction its appearance gives.

(2) That the author was not consciously concerned to create a work of art is not determinative.

(3) Whether something is or is not artistic is a question of fact, to be decided in the light of evidence, and it is pointless to try to expound the meaning of the word.

(4) 'Work of artistic craftsmanship' is a composite phrase, to be construed as a whole, and it is a mistake to consider the terms 'craftsmanship' and 'artistic' in isolation from one another.

(5) The word 'artistic' is for the court to interpret, not witnesses. The true test is whether the author has been consciously concerned to produce a work of art.

However, the tests set down in George Hensher Ltd $v$ Restawile Upholstery (Lancs) Ltd were criticised in Laddie, Prescott \& Vitoria as being inconsistent and unhelpful. ${ }^{3}$ Laddie proposes an alternative test, which carefully avoids a situation where the judge is asked to be the arbiter of whether or not the work is a work of art. Instead it proposes a test in which the reaction to the work of members of the public is objectively assessed:

In the case of a work of artistic craftsmanship the medium is the working of materials by manual dexterity (craftsmanship); and the visual appearance is significant if it would cause at least some members of the public to wish to acquire and retain the object on especial account thereof: an objective fact, capable of ascertainment. Whether this public is or is not well advised is a matter of absolutely no concern to the court; the other ingredients of the question are well within its sphere of competence of adjudication. ${ }^{4}$

\footnotetext{
3 Laddie, Prescott \& Vitoria, The Modern Law of Copyright and Designs (5th edn, LexisNexis, 2018), para 4.37.

4 Lord Reid in Hensher v Restawile Upholstery (Lancs) Ltd [1976] AC 64.
} 
This latter test does appear to be the better one. It is certainly preferable to base the test on an analysis of public reaction to a work than to burden the judge with the responsibility of assessing artistic merit.

\subsubsection{The requirement of originality}

As we have seen, s 1(1) of the CDPA 1988 requires not only that the work be an artistic work, but that it be 'original'. It is therefore a fundamental requirement for copyright protection of an artistic work that the work be original. ${ }^{5}$ Having established that the work is of a type which is capable of copyright protection as an artistic work, the second step is to determine whether or not it is original. If it is not original it will not benefit from copyright protection. The concept is not defined in statute, but has been considered extensively by the courts. In University of London Press Limited v University Tutorial Press Limited, ${ }^{6}$ the court concluded that the threshold for originality was low and that it is not necessary that the idea behind the work should be original. Few ideas are wholly original and artists take their inspiration and ideas from others and from tradition. Rather, the originality required is the originality of expression of the idea. However, even the expression of the idea does not need to be novel to be original. It is sufficient that it should originate from the author and must not be copied from another work. It is also accepted that some degree of skill and labour on the part of the author is required for the work to be original - but that degree of skill and effort can be minimal. ${ }^{7}$

A striking illustration of just how low the threshold for originality is can be seen by the protection given to photographs. Whereas a photocopy of an image is unlikely to involve sufficient skill and labour to attract copyright protection, a photograph of an object or image is protected by copyright even though the originality and creativity involved in taking the photograph can amount to no more than pointing and clicking. This means that a photograph of a painting is itself capable of being a copyright work distinct from the painting which is the subject of the photograph. 


\section{Example}

- When an auction house photographs a work of contemporary art by Damien Hirst for its sale catalogue, the photograph itself becomes a copyright work owned by the auction house. Anyone wishing to reproduce the photograph will need to obtain the consent of Damien Hirst to reproduce the image of the artwork, but also the consent of the auction house to reproduce the photograph of the artwork. ${ }^{8}$

The requirement of originality is often discussed and illustrated in the context of contemporary artworks, which frequently celebrate ordinary objects. Think for instance of Andy Warhol's soup cans. Andy Warhol's images are typical of what is sometimes known as the art of appropriation. This form of art takes brands, images and objects which are part of our culture and incorporates them into artwork. We have seen that it is not a requirement that the artistic work should be an original, novel or inventive idea or thought. So once again, the fact that the soup can design already existed and is illustrated elsewhere plays no part in deciding whether or not it is original. Equally, in the context of installations and objets trouvés, the originality lies not in the object but the fact that it has been taken out of its context and placed in an artistic context.

The question is, then: is the expression of Andy Warhol, in the depiction of the soup can as a screen print, an original expression? The starting point for determining this question is that the artwork must be different from other versions of the image. It must not be copied from another work. Second, it should originate from the author. Finally, to be original the artwork must involve an exercise by the artist of skill, labour and judgement. In this case Warhol was not simply copying the can label - he expanded it and reproduced it as a screen print using skill and labour. The work therefore did satisfy the requirement of originality of expression.

However, an exact copy of the Warhol screen print by another artist would not be an original work because it is neither an original expression of the idea nor involves skill, labour and judgement. An artwork copied from another work will not enjoy copyright protection in its own right if it is simply an exact copy of the work of another artist.

8 See Laddie, Prescott \& Vitoria: The Modern Law of Copyright and Designs (5th edn, LexisNexis, 2018) at para 4.37 for more detail regarding cover photographs and originality. 
However, if there is an element of embellishment or alteration, it may be protected.

It is also worth bearing in mind, though, that while the Andy Warhol soup can screen print and canvases may pass the originality test and therefore be protected by copyright as an original artwork, the Campbell soup company also has intellectual property rights in the copying of its logo, including copyright. So the reproduction of the Campbell logo in the artwork would require the consent of the Campbell soup company. In practice, however, this issue never arose, as the Campbell soup company was quick to recognise the advertising value it gained from the Warhol soup cans and did nothing to prevent or restrict Warhol's use of the logo. It is said that they even sent him a couple of cases of tomato soup as a thank you.

\subsubsection{Originality and photographs}

Photographs are different from many other artworks in that a photograph is in itself a form of reproduction which can require little or no originality or labour beyond the pressing of the camera button. For this reason it is worth considering the status of photographs in the context of copyright. The question of copyright in photographs is increasingly important given the advent of smartphones, which allow us to create, alter and distribute many thousands of photographs. Social media also encourages us all to be creative and share images, making us all amateur photographers. We have also seen that under United Kingdom law the threshold for originality is very low. As a result, provided that there is some judgement involved in choice of angle, exposure or timing, even a snapshot of a subject photographed by many others, or a snapshot of a building, object or scene, will benefit from its own distinct copyright protection. It is for this reason that, as we have seen above, a photograph taken by an auction house or dealer of a painting for the sale catalogue will be a copyright work in its own right. This is because, just like a snapshot by a tourist, a photograph for cataloguing purposes will require some degree of originality in choice of lighting and exposure. On the other hand, a photocopy of an image will not be protected by copyright as the placing of the image on the photocopier glass and pressing the copy button requires no originality or labour. This low originality threshold requirement has been exploited by artists such as Richard Prince. Prince's art involves the 're-photographing' of photographs taken from magazines, posters and advertisements, but reproducing them with often very subtle changes. As a part of the 
Frieze Art Fair in New York in 2015, Prince displayed significantly enlarged screenshots of Instagram posts which he had come across on the internet. He believes he was able to do this without infringing the copyright of the people who posted the images on Instagram because he modified the captions accompanying the photograph in each case. His argument is based upon a previous case brought against him in the US courts by photographer Patrick Cariou, in which the United States Court of Appeals for the Second Circuit ruled that Prince's appropriation art could constitute fair use and that a number of his works were transformative fair uses of Cariou's photographs. ${ }^{9}$ At the time of writing this position is now due to be tested in court, as Richard Prince is the subject of a further lawsuit over one of the Instagram images in the 2015 Frieze Art Fair, brought by photographer Donald Graham. ${ }^{10}$ The law of fair use under UK law is considerably narrower than in the US, so it is unclear whether Cariou would have been successful in the UK courts.

\subsubsection{Duration of protection}

Even where an artwork is protected by copyright law, that protection is limited in time. After the expiry of the copyright protection period, the consent of the copyright owner is no longer required for reproduction or distribution of the artwork.

Since 1996, copyright protection has expired 70 years after the death of the artist. ${ }^{11}$ So, for example, Picasso died on 8 April 1973, so copyright in works by Picasso will continue until 70 years from 31 December 1973, which is 31 December 2043.

Prior to 1996, the period of copyright protection was the lifetime of the artist plus 50 years. Extending the copyright period from 50 to 70 years had the effect of bringing back into copyright works where copyright had previously expired. So, for example, in 1995 the works of an artist such as Paul Klee, who died in 1940, were no longer protected by copyright and could be freely copied. But one year later the 70 year rule extended copyright, so that the artist's work came back into copyright until 2010.

9 Cariou v Prince, 714 F. 3d 694 (2d Cir. 2013).

10 Before the Southern District Court of New York, not yet decided.

11 CDPA 1988, s 12(2), as amended by the Duration of Copyright and Rights of Performances Regulations 1995 (SI 1995/3297). 


\subsubsection{Ownership of copyright}

Purchasers of artworks frequently have the misconception that they own the copyright in the artwork they have purchased. In fact they have almost always purchased only the object itself, and the copyright remains with the copyright owner - usually the artist. What this means is that while the proud owner of the work can hang his or her new painting wherever he or she wishes, he or she cannot make or sell reproductions of the work without the consent of the copyright owner. It is of course possible for the artist to assign copyright to the buyer on sale of the work, but this is very unusual.

\subsubsection{Artworks created in the course of employment}

The usual rule is that the author of an artwork is the first owner of copyright in the work (CDPA 1988, s 11(1)). However, where an artwork or photograph is created in the course of employment after 31 July 1989 (the date the CDPA 1988 came into force), the first owner of the copyright in the work will be the employer, unless there is an agreement to the contrary (s 11(2)). For works which were created by employees in the course of their employment on or prior to 31 July 1989, the Copyright Act 1956 provides that the owner of the copyright will be the employer, except where the employer is the proprietor of a newspaper or magazine. Where the employer is a newspaper or magazine proprietor, the employer shall have the right to the copyright in the artwork and the right to reproduce the artwork only in so far as is related to the publication in the magazine or newspaper. All other copyright remains with the employee (Copyright Act 1956, s 4(2)).

\subsubsection{Commissioned artworks}

A similar presumption applies in relation to commissioned artworks. Section 4(4) of the Copyright Act 1956 provides that where, after 1 June 1957 but before 1 August 1989, an artist was commissioned by a person to take a photograph, draw or paint a portrait or make an engraving or sound recording and the artist was remunerated in money or money's worth, the person who commissioned the artwork rather than the artist would be the first owner of the copyright unless there was an agreement to the contrary.

No express provision is made in the CDPA for artworks commissioned on or after 1 August 1989. As a result, copyright in such works 
will remain with the artist who created the work, unless there is an agreement to the contrary in which the artist assigns the copyright in the artwork to the commissioner. For this reason it is important for commissioners of works of art to set out in a written agreement the intended ownership of the copyright in the commissioned work.

\subsubsection{Joint artworks}

Where an artwork has been created jointly or where the copyright in the work has been assigned so that it is owned jointly, the copyright may be owned by more than one person. In such circumstances, the first question is whether the joint owners own the copyright as tenants in common - so that each owns a percentage interest - or as joint tenants, where the interest is jointly held by both authors and each have equal rights over the whole artwork. In the latter case the ownership of the copyright passes to the surviving joint owner on the death of a joint owner. In the former case it does not, and the deceased joint owner's interest can be passed on to a third party in a will. Either form of joint ownership is possible and will depend on the circumstances or upon the agreement between the joint owners.

In either case, no part owner may deal with the copyright in the work without the consent of the coowner.

\subsubsection{Copyright infringement}

So what protection does copyright provide? Once covered by copyright, the agreement of the copyright owner will be required to:

(a) reproduce the work in any material form (CDPA, s 17);

(b) issue copies of the work to the public (CDPA, s 18);

(c) rent or lend the work to the public (CDPA, s 18A);

(d) communicate the work to the public (CDPA, s 2o).

A failure to obtain permission for any of these acts will constitute an infringement of copyright, which may entitle the copyright owner to damages and/or a court order preventing further infringements and/or requiring the destruction of infringing copies. 


\subsubsection{Liability for infringement}

Each person who commits an infringing act is of course liable for the infringement, but the Act also extends potential liability to others. A person who imports into the United Kingdom an infringing copy of an artwork may be liable for infringement (CDPA 1988, s 22). Equally, a person who possesses an infringing copy in the course of a business (s 23(a)); sells, hires out or exhibits an infringing copy for sale or hire (s 23(b)); or exhibits in public or distributes an infringing copy (s 23(c)) may also be liable as a secondary infringer. Knowingly providing the equipment necessary for making infringing copies is also an act of infringement (s 24).

\subsubsection{Reproduction or copying}

Reproducing a copyright work in any material form means producing a copy of the work. In its simplest form this will mean the making of a facsimile copy such as a photocopy of the work. It will, however, also include the creation of an electronic copy of a copyright work stored on a computer or disc. It will also include making a two dimensional reproduction of a three dimensional object, such as a sculpture - or, indeed, a three dimensional reproduction of a two dimensional work (s 17(3)). There is no numerical minimum on the extent of the reproduction. Making a single unauthorised copy of a copyright artwork is an infringing act.

\subsubsection{Issuing and communicating copies to the public}

The issuing of copies to the public means putting copies of the artwork into circulation. Traditionally this would have been done through publication of the work in a book or magazine. Today publication is, however, just as likely - indeed, more likely - to occur through circulation on the internet, for example on social media or on a website. Such acts are also covered by the infringement of communicating the work to the public.

\subsubsection{Rental or lending}

As noted above, the rental or lending of copies of a copyright artistic work - or the original work itself - to the public is a restricted act under $\mathrm{s} 18$ of the CDPA 1988. It does not, however, apply to works of applied art. Applied art for these purposes is the application of design 
and decoration to everyday objects to make them aesthetically pleasing, as opposed to traditional forms of art such as drawing and painting. However, the terms 'rental' and 'lending' do not include public performances, exhibiting or showing in public (s 18(3)(a) and (b)). Nor does s 18 apply where copies of works or the works themselves are made available between establishments which are accessible to the public.

\subsubsection{Substantial part}

We have seen above that copyright protection may extend not only to the whole of the artwork, but also to substantial parts of it (s 16(3)). Where the artwork or an element of the artwork has been copied not in whole but in part, the question arises whether the part copied is sufficiently substantial to be considered protected by copyright. It has been established that the substantiality test should be about the quality of the part reproduced rather than the quantity. ${ }^{12}$ It follows that the part will be considered substantial if the part reproduced expresses the artist's intellectual creation. That can only be determined on a case by case basis, looking at the artwork and taking account of the overall impression of the reproduction.

\subsubsection{Inexact copies and imitation}

In some circumstances the issue is not the substantiality of the part of an artwork reproduced but the proximity of the reproduction to the original copyright protected artwork. Where an artwork has been imitated rather than slavishly reproduced, whether or not the imitation amounts to copyright infringement can only be determined on a case by case basis. In doing so it is important to remember that the protection afforded by copyright law does not extend to an idea, but to the expression of an idea. So, what is required is an analysis of what elements of the artist's artwork were copied. If the sum of those elements is sufficiently original as an expression of an idea, then the imitation or inexact copy may not amount to an infringement of copyright.

\subsubsection{Fair dealing}

There are certain limited circumstances where a copyright work can be reproduced in the United Kingdom without the consent of the copyright owner. This is loosely known as 'fair dealing'. The term should not

12 Ladbroke (Football) Ltd v William Hill (Football) Ltd [1964] 1 All ER 465, [1964] 1 WLR 273, HL. 
be confused with the US concept of fair use, which is less specific and of potentially broader ambit.

\subsubsection{Private use}

Section 28 B of the CDPA 1988 permits the making of a copy of a copyright work by an individual provided the copy is of the individual's own copy of the work. However, it must be for the individual's private use and made for noncommercial purposes. It will also become an infringing act if the copy is passed on to a third party.

\subsubsection{Research purposes}

Section 29(1) of the CDPA 1988 specifically permits the reproduction of copyright material for the purposes of research for a noncommercial purpose provided that it is accompanied by a sufficient acknowledgement. Fair dealing for the purposes of private study also does not infringe copyright (CDPA 1988, s 29(1C)). For example, a student photocopying images of an artwork in the course of research for a thesis would not need to seek the consent of the copyright owner.

\subsubsection{Criticism or review}

Section 30 of the CDPA 1988 similarly allows the copying of copyright material for the purposes of criticism or review, provided once again that the reproduction is accompanied by a sufficient acknowledgement and provided that the work in question has been made available to the public.

\subsubsection{News reporting}

The reproduction of a copyright work for the purposes of news reporting is also permitted as fair dealing under the CDPA 1988, s 30, although the author must be acknowledged. It is also important to note that the reproduction of photographs in the context of news reporting is excluded from this exemption. A newspaper is therefore able to publish a reproduction of a copyright artwork which has recently been sold at auction on the grounds that this is 'fair dealing' for the purposes of s 30 of the CDPA 1988. However, where the newspaper is seeking to reproduce a photograph of the copyright artwork taken by a photographer, the consent of the photographer, as the copyright owner of the photograph, will need to be obtained. 


\subsubsection{Caricature, parody and pastiche}

Section 30A of the CDPA 1988 permits the reproduction of a copyright work for the purposes of caricature, parody or pastiche. It is sometimes the case that well known artworks are parodied in a way which involves taking some recognisable part of the original copyright work. While this sort of parody is permitted under the CDPA 1988, it is only permitted to the extent that it can be considered as 'fair dealing'. This is a question of degree which must be assessed by the court in each case. A cartoonist could, for instance, include as part of a cartoon a well known work by the graffiti artist Banksy. That would not amount to an infringement. However, a facsimile reproduction of the Banksy artwork with a funny caption underneath would probably not amount to fair dealing. Equally, a parody which causes or is likely to cause economic damage to the copyright holder may not be considered 'fair dealing'.

\subsubsection{Advertisement of a copyright artwork for sale}

A further important exception is the right under s 63 of the CDPA 1988 to reproduce an artwork for advertising purposes for the sale of the artwork. This means that copyright consent is not required for the illustration in an auction house sale catalogue of an artwork being offered for sale. Nor is it required for an artwork illustrated on a website or Instagram feed as being for sale. It will, however, be required where other similar works, which are being offered for sale, are illustrated in the catalogue by way of comparison and context. Also, once the work has been sold the exemption no longer applies, so care needs to be taken following the sale to obtain copyright consent for any further commercial use of the image of the sold work.

\subsubsection{The internet}

The internet presents a practical challenge to the notion of copyright. The challenge it raises is not so much whether an artist's rights are protected on the internet, but whether those rights are capable of being policed and enforced.

\subsubsection{A haven for copyright infringement?}

As we photograph and record our surroundings on our smartphones and post those images to the internet on social media, very few of us 
give thought to the notion of copyright infringement. The internet is sometimes treated as a copyright-free area. That is certainly incorrect from a legal perspective. The reproduction and distribution of a copyright protected work on the internet is no different from a reproduction and distribution of the work on paper. A copyright owner has every right to prevent the unlicensed reproduction of his or her work on the internet. However, the difficulty lies in the ability to enforce that right. First, there is the challenge of identifying the infringer, who can be located anywhere in the world. Then there are the often prohibitive costs of asking the courts to recognise those rights. Finally, armed with a court decision in his or her favour, the copyright owner will need to enforce those rights - often only to find that the infringer has disappeared or has no assets. All of these factors make it difficult for copyright owners to seek to assert their rights in most cases of infringement, and it is only worthwhile to do so in major cases of infringement.

\subsubsection{Social media}

Given the fact that even everyday photographs benefit from copyright protection, users of Facebook, Instagram, Twitter and other social media applications may be concerned about the copyright status of images that they post on social media sites. At the time of publication, sites do not seek to acquire ownership in works posted on their sites, but those who use their services are deemed to have agreed to give the social media site a royalty-free unlimited licence to use the images. This, it could be argued, is little different in effect to an assignment of the copyright. The copyright owner loses control over the image. So, if you are an artist or if you are concerned about guarding the copyright in your images, thought should be given to the consequences of posting images on social media.

Instagram is typical in this regard. Its terms and conditions of use provide: 'Instagram does not claim ownership of any Content that you post on or through the Service. Instead, you hereby grant to Instagram a non-exclusive, fully paid and royalty-free, transferable, sub-licensable, worldwide license to use the Content that you post on or through the Service, subject to the Service's Privacy Policy.'

Facebook provides: 'For content that is covered by intellectual property rights, like photos and videos (IP content), you specifically give us the following permission, subject to your privacy and application settings: you grant us a non-exclusive, transferable, sub-licensable, royalty-free, 
worldwide license to use any IP content that you post on or in connection with Facebook (IP License). This IP License ends when you delete your IP content or your account unless your content has been shared with others, and they have not deleted it.'

\subsubsection{Online art sales databases}

The growth of the internet has led to the establishment of a number of online databases listing art sales data, including images of the artworks. In those cases the images themselves may require copyright consent. In addition, where the images of the works are taken from an auction house or dealer's online catalogue, the consent of the auction house or dealer - as the owner of the copyright in the photograph - may be required.

\subsubsection{Artworks created by artificial intelligence}

In 2018 Christie's caused a sensation by selling Portrait of Redmond Belamy, created by artificial intelligence, for US $\$ 432,500$, nearly 45 times its published estimate. Portrait of Redmond Belamy depicted a man dressed in a frock coat with a white collar showing. The appearance of the work was as though it was unfinished, with the facial features of the man blurred and indistinct. The areas of canvas surrounding the portrait are also left blank. The work had been signed using the mathematical formula of the algorithms used to create it.

The work was the brainchild of a Paris-based collective called Obvious. It was created using a technology called the Generative Adversarial Network algorithm (GAN). Composed of a two part algorithm - the generator and the discriminator - the system was fed a data set of 15,000 portraits painted between the fourteenth and twentieth centuries. The generator created new images based on this set, while the discriminator reviewed all outputs, comparing the product of the algorithm with the pieces painted by human hands until it couldn't tell the two apart. Once the computer algorithm had generated the image, this was then printed in ink on canvas. The objective of Obvious was to show that machines can be creative, just like humans.

The question, then, is whether a work which is generated by artificial intelligence is capable of being protected by United Kingdom copyright law. As we have seen, there is a requirement under United Kingdom law for the work to be 'original'. While the level of originality required 
is low, a human author must be involved. Section 9(3) of the CDPA 1988 does however explicitly allow for the possibility that copyright works can be computer generated in the sense that they are 'generated by a computer in circumstances such that there is no human author of the work' (CDPA 1988, s 178). In these circumstances s 9(3) of the CDPA 1988 deems the author to be the person by whom the arrangements necessary for the creation of the work are undertaken. In the case of the painting sold by Christie's, then, it will be the human user or programmer of the GAN tool.

If in the future artworks are able to be created fully autonomously, with no human intervention of any sort, then such works will not benefit from copyright protection.

\subsection{Moral rights}

\subsubsection{Introduction}

Moral rights are a series of rights given to artists by the CDPA 1988 Ch IV (ss 77-89) to ensure that the artist is given due recognition for creating the artwork and that the work is not used or reproduced in a way of which the artist does not approve.

Moral rights are a concept which originated in non-common law countries such as France, where the artist and his or her descendants are seen as the guardians of artwork and the artist's oeuvre. Common law countries such as the United Kingdom have tended to use as the starting point the licensed owner of the copyright - which may or may not be the artist. It is perhaps for this reason that common law countries refer to 'copyright' and 'intellectual property', while in France the law is referred to as the 'Droits d'Auteur' (Author's Rights). Until the CDPA 1988 there was no express provision in UK copyright law protecting the paternity and integrity rights of the artist or author of a work. However, with the introduction of the CDPA 1988 the United Kingdom adopted the concept of moral rights in line with the 1928 Berne Convention for the Protection of Literary and Artistic Works.

It is important to bear in mind that a moral right can only exist where the work in question is protected by copyright. Also, because these rights were first introduced in the CDPA 1988, the protection of 
paternity and integrity rights do not apply to any act which occurred before August 1989. ${ }^{13}$

These moral rights have assumed greater importance to artists with the rise of digital communication, where images are copied, altered, incorporated into other images or contexts and distributed without credit or attribution with a few clicks of a mouse button. However, the extent and the ease with which this happens has meant that enforcing those rights has become extremely difficult. Communication on the internet through Facebook, Instagram, Snapchat and Tumblr is increasingly focused on images, and those images are routinely altered or doctored and are rarely attributed to the original author. This raises the wider question of whether, without a means of effective enforcement, the concept of moral rights can survive the advent of digital communication.

\subsubsection{Moral rights}

The moral rights, which apply to the whole work or any substantial part of it, are:

- The right of an artist to be clearly and reasonably prominently identified whenever the artist's work is commercially published, exhibited to the public or included in a broadcast or film. This is known as the Right of Paternity.

- The right of the artist to object to a reproduction or representation of the artwork in a way which the artist feels is derogatory. This is known as the Right of Integrity.

- The Right of False Attribution, which is the right not to be identified as the creator of a work created by someone else.

- The right of someone who has privately commissioned a photograph or film not to have copies of the work displayed or broadcast publicly. This is known as the Right to Privacy.

Under s 87 of the CDPA 1988 all of these rights can be waived by the person giving up the right, but the waiver must be in writing. The waiver may relate to a specific work, to works of a specified description

13 CDPA 1988, Sch 1, para 22(1). 
or to works generally, and may relate to existing or future work. It may be conditional or unconditional and may be expressed to be subject to revocation. However, moral rights, unlike copyright, cannot be assigned, sold or given away to anyone else by the owner of the moral right (CDPA 1988, s 94).

When the owner of the moral right dies the right shall pass:

(a) By descent to whomever the deceased person has designated in his or her will; or

(b) if there is no provision in the will but the copyright in the work in question forms part of the deceased's estate, to whomever the estate passes, and

(c) if neither (a) nor (b) applies the decision as to who the moral rights shall pass to is for the deceased's personal representatives to make. (CDPA 1988, s 95)

\subsubsection{Right of paternity}

The right of an artist to be identified as the author of an artistic work applies where the work is published commercially or exhibited in public, or a visual image of the work is communicated to the public.

The right applies not only to artworks in the traditional sense, such as paintings, but also to sculpture, works of architecture, models of buildings, works of artistic craftsmanship more generally, and copies of graphic works or photographs which depict a work of art, where these are issued to the public.

The right also applies to films, and the director of a film has the right to be identified whenever a film is shown in public or copies of the film are made available to the public.

However, the artist needs to assert the right to paternity. In layman's terms this means that the artist needs to have laid claim to authorship of the work (CDPA 1988, s 78). This is usually done by the artist signing the work or subsequently notifying others of his authorship of the work.

As noted above, because the concept of moral rights was first introduced by the CDPA 1988, the right of paternity does not apply to artworks where the author died before 1 August 1989. 
There are some works to which the right does not apply (CDPA 1988, s 79). The right does not apply to artworks which are a computer program, a typeface design or a computer generated work. Nor does it apply in connection with a reproduction of a work which has been specifically created for inclusion in a newspaper magazine or reference book and published with the author's consent. Nor does the right apply where the artwork is depicted in the course of reporting current events through a sound recording, film or broadcast.

\subsubsection{The right of integrity}

The right of integrity under s 8o of the CDPA 1988 protects artists from having their artworks subjected to derogatory treatment such as a 'distortion' or 'mutilation' of the original work or alteration in a way that harms the author's reputation or honour.

The right applies where the artwork or images of the artwork are published or broadcast commercially, where the artwork is exhibited publicly or where copies of the work are issued to the public (CDPA 1988, s 8o(4)).

Derogatory treatment amounts to altering or adapting the work in a way which amounts to distortion or mutilation of the work or in a way which is otherwise prejudicial to the honour or reputation of the artist (CDPA 1988, s 8o(2)(b)).

This fairly wide definition is generally considered to mean that artworks must be depicted or exhibited in full and without alteration. So, for instance, a magazine with an image of painting on its cover could be infringing the moral right of integrity of the artist if it were to depict only a detail or a part of the artwork, or if it were to reproduce the artwork in full with lettering across part of the image. As for the extent of the infringement, there is no requirement for the alteration or distortion to affect a substantial part of the artwork, so even a minor breach constitutes an infringement.

Perhaps surprisingly, s 80 of the CDPA 1988 does not envisage the destruction of the artist's work as amounting to derogatory treatment. There have been instances of the actual or threatened destruction of artists' works, and in such cases - under UK law, at least - the artists have been unable to intervene. Graham Sutherland's portrait of Sir Winston Churchill, commissioned by parliament, was famously 
destroyed by Lady Churchill as she did not like it. The Japanese businessman Ryoei Saito, who bought Van Gogh's Portrait of Dr Gachet in 1990 for US\$82.5m, is said to have threatened to have the painting cremated with him upon his death. More recently the graffiti artist Banksy destroyed one of his own works using a shredder incorporated into the artwork's frame. The shredder was triggered, for dramatic effect, immediately after the artwork was sold at a Sotheby's auction in October 2018. Of course, where the artist himself destroys the work, there can be no question of moral rights infringement.

Another interesting question surrounds the context of the display and placement of artworks. Can an artist object if, for instance, his or her work is displayed alongside other works which the artists feels are demeaning, such as pornographic or religious works? Or can the artist object if his or her work is grouped with other works in a museum exhibition with a controversial title? The question has not yet been addressed by the courts.

An interesting situation arose in France in 2015 in connection with a sculpture by Anish Kapoor entitled Dirty Work. The work was exhibited in the grounds of the Palais de Versailles. The sculpture was vandalised when yellow paint was thrown over its interior. Kapoor asked that the paint be removed. The artwork was then once again vandalised, but on this occasion with antisemitic graffiti. Kapoor decided that the artwork should remain in its vandalised state as he did not want to allow the act of violence and intolerance to be erased. In France moral rights are more extensive than in the United Kingdom, giving artists the right to insist on the completion of a commissioned work, the right to withdraw an artwork and the right to prevent its destruction. It might be thought that Kapoor's insistence that the sculpture remain in its vandalised state would be respected as an expression of his moral rights. However, a local Versailles councillor disagreed and filed a complaint with the French courts demanding that the graffiti or the sculpture be removed on the grounds that leaving it in its present state incited racial hatred. The French court agreed and ordered the removal of the graffiti.

\subsubsection{The right of false attribution}

Under s 84(a) of the CDPA 1988 a person has the right not to have a literary, dramatic, musical or artistic work falsely attributed to him as author and, in the case of a film, not to have a film falsely attributed 
to him as director. An 'attribution' can be an express or implied statement as to who is the author of the work or the director of the film.

For there to be an infringement, the two elements must exist. First, there must be a false attribution; second, the person making the attribution must do so knowing it to be false.

Specifically, s 84(2) of CDPA 1988 requires that in order to constitute an infringement the work must be exhibited to the public or copies of the work must be issued to the public accompanied by a false attribution of authorship. And, as we have seen, the person doing so must know or have reason to believe that the attribution is false (CDPA 1988, $\mathrm{s} 84(4))$. A person also infringes the right if, in the course of a business, he possesses or deals with a copy of a work in relation to which there is a false attribution if he knows or has reason to believe that there is such an attribution and that it is false (CDPA 1988, s 84(5)). An auction house or dealer knowingly handling a work which is falsely attributed to an artist is therefore at risk of action by the person to whom the work has been falsely attributed. In addition, a false representation that such a work is an adaptation of the work of a person is actionable in the above circumstances. This section will also apply where a copy of an artistic work is falsely represented as being a copy made by the author of the artistic work (CDPA 1988, s 84(6)(b)).

In contrast to the other moral rights listed above and below, which subsist for as long as copyright exists, the right of false attribution expires 20 years after the death of the person to whom the work is falsely attributed.

Most cases in which the right of false attribution has been an issue in the United Kingdom have centred upon literary works. ${ }^{14}$ The right is, however, important for artists who want to protect their brand and in particular ensure that dishonest traders cannot use their name to sell works or copies of works which were not created by the artist.

The importance of protection of this kind for artists was emphasised in a bizarre US case in 2016. A former prison corrections officer, Robert Fletcher, and an art dealer, Peter Bartlow, tried to sell a work which they claimed was by the artist Peter Doig. Doig, however, refused

14 See for instance Clark v Associated Newspapers Ltd 19881 All ER 959, in which the court held that the format of parodied diaries in the Evening Standard said to be by Alan Clark was deceptive. 
to authenticate it on the grounds that he had not painted the work. Fletcher sued Doig for US $\$ 5,000,000$ and a declaration of authorship, claiming that he had bought the work - a desert landscape - from Doig for US $\$ 100$ while he was incarcerated at the Thunder Bay Correctional Centre, where Fletcher worked. Fletcher claimed he bought it to ensure that the painter, whom he said had been jailed on an LSD charge, would not go back to selling drugs. Doig was successful in proving that he was not the author of the work, and that he had never been incarcerated in Thunder Bay Correctional Centre on any charge. The claim therefore failed.

\subsubsection{The right to privacy in privately commissioned photographs and films}

Any person who, for private and domestic purposes, commissions the taking of a photograph or the making of a film on or after 1 August 1989 has the right under s 85(1) of the CDPA 1988 not to have copies of the work issued to the public, or the work itself exhibited or shown in public or communicated to the public. It is also an infringement of that right for anyone else to authorise others to do any of these things.

However, it is important to note (CDPA 1988, s 85) that the right is not infringed by an act which the CDPA 1988 deems to be an exception to copyright infringement. These include:

(a) S 31 (incidental inclusion of work in an artistic work, film or broadcast);

(b) S 45 (parliamentary and judicial proceedings);

(c) s 46 (Royal Commissions and statutory inquiries);

(d) 550 (acts done under statutory authority);

(e) $\mathrm{s} 57$ or $66 \mathrm{~A}$ (acts permitted on expiry of copyright).

\subsubsection{Application of moral rights}

\subsubsection{Collaborative works and joint authorship}

In the case of a work of joint authorship, each author has his own separate right of paternity (CDPA 1988, s 88(1)) and right of integrity 
(CDPA 1988, s 88(1)). However, where the right of paternity is concerned, each of the coauthors must have independently asserted their rights of paternity.

\subsubsection{Duration of moral rights}

The right to be identified as author, the right to object to derogatory treatment and the right to privacy of certain photographs and films continue to subsist as long as copyright in the artwork subsists, this being the life of the artist plus 70 years. The right to object to false attribution however expires 20 years after the artist's death (CDPA 1988, s 86).

\subsubsection{Enforcement of moral rights}

There are a wide variety of remedies for breach of moral rights, such as injunctions preventing the exhibition or distribution of, or other prohibited acts relating to, the work in question. Damages are also available unless the defendant is able to prove that at the time of the infringement he or she did not know, and had no reason to believe, that copyright subsisted in the work to which the action relates (CDPA 1988, s 97). The court may also order that infringing copies of works should be delivered up to the claimant by the defendant (CDPA 1988, s 99).

The CDPA 1988 also authorises the holder of the right, in certain circumstances, to take the law into his or her own hands. Section 100 of the CDPA 1988 provides that where an infringing copy of a work is found on sale or exhibition, that work can be seized and detained by the copyright owner or by a person authorised by him. However, there are some fairly extensive conditions which limit the use of this right. Before anything is seized under this section, notice of the time and place of the proposed seizure must be given to a local police station. The right only extends to places where the public have access, but the right cannot be exercised where the object to be seized is to be found at a person's permanent or regular place of business, nor can any force be used to effect the seizure. When anything is seized under $\mathrm{s} 100$ a notice must be left in a prescribed form containing details of the person by whom or on whose authority the seizure is made and the grounds on which it is made. 


\subsection{Artist's resale right}

\subsubsection{Introduction}

French and German law have long incorporated the concept of the artist's right to be remunerated in relation to sales which occur subsequently to the first sale of the artwork. This was designed to address the concern that an impecunious artist who has sold his artworks for very little might later see his artworks changing hands for significant sums. The solution - a mechanism known in France as 'Droit de Suite' - was designed to ensure the artist and his estate would be entitled, for as long as the artwork was in copyright, to receive a proportion of the proceeds of sale each time his artwork is sold - similar to the royalty an author receives upon each sale of his book. Originally Droit de Suite applied only to auction sales but it has since been widened to apply to all forms of resale.

This concept did not exist in common law countries, and the proposal by the European Commission to incorporate the Droit de Suite into the laws of all European Union member countries was initially resisted by the United Kingdom. However, the measure was eventually pushed through, resulting in the European Parliament and Council Directive (EC) 2001/84 (OJ L272, 13.10.2001, p 32. Droit de Suite was therefore incorporated into United Kingdom law through the Artist's Resale Right Regulations (ARR) 2006. ${ }^{15}$

It is important to note that the most significant art markets outside the European Union, including the United States and Hong Kong, do not level an artist's royalty on resales.

\subsubsection{Artist's resale royalty in the United Kingdom}

\subsubsection{Sectors of the art market are affected by the artist's resale royalty}

Because the royalty is payable while the artist is living and for 70 years thereafter, the sectors of the art market which are primarily affected by the artist's resale right are sales of modern, ${ }^{16}$ postwar, and contemporary art, ${ }^{17}$ which account for approximately $75 \%$ of the UK fine art market by value. ${ }^{18}$

15 SI 2006 (ARR 2006).

16 Modern is defined for these purposes as an artist born between 1975 and 1910.

17 Postwar and contemporary is defined for these purposes as artists born after 1910.

18 British Art Market Federation Report, The British Art Market, 2017. 


\subsubsection{Types of artwork liable to artist's resale royalty}

The ARR applies to graphic or plastic artworks which are protected by copyright, such as pictures, collages, paintings, drawings, photographs engravings, prints, lithographs, tapestries, ceramics or glassware (ARR 2006, reg 4(1)).

Posters of a graphic work which are authored by a named artist are covered by the ARR but commercial reproductions of artworks in the form of unlimited posters and prints do not qualify. This is because a copy of an artwork is not to be regarded as a work qualifying for the artist's resale royalty unless the copy is one of a limited number made by the artist or under the artist's authority (ARR 2006, reg $4(2))$.

It is to be noted that the definition of works covered by the resale right in the ARR 2006 does not include furniture, silverware or jewellery.

\subsubsection{The nationality of the artist}

The artist must be a natural person who is a national of an EEA state, ${ }^{19}$ or a national of one of the countries listed in Schedule 2 countries outside the EEA whose nationals may enjoy resale right. ${ }^{20}$

\subsubsection{When is the artist's resale royalty payable?}

The royalty is aimed at the 'secondary market' - transactions which take place after the first transfer of ownership of an artwork by the artist (ARR 2006, reg 3(1)). As a result, the royalty is not payable on the first transfer of ownership from the artist, ${ }^{21}$ but is payable on each subsequent sale of the work.

\footnotetext{
19 Austria, Belgium, Bulgaria, Croatia, Republic of Cyprus, Czech Republic, Denmark, Estonia, Finland, France, Germany, Greece, Hungary, Ireland, Italy, Latvia, Lithuania, Luxembourg, Malta, Netherlands, Poland, Portugal, Romania, Slovakia, Slovenia, Spain, Sweden and the UK.

20 Algeria, Brazil, Bulgaria, Burkina Faso, Chile, Congo, Costa Rica, Croatia, Ecuador, Guinea, Iraq, Ivory Coast, Laos, Madagascar, Mali, Monaco, Morocco, Peru, Philippines, Romania, Russian Federation, Senegal, Serbia and Montenegro, Tunisia, Turkey, Uruguay.

21 A first transfer will include transfer of ownership from the from the artist by inheritance or by the artist's personal representatives for the purposes of the administration of his estate, and disposal of the work by an official receiver or a trustee in bankruptcy.
} 


\subsubsection{What type of resale triggers the resale royalty entitlement?}

'Sale' for the purposes of the ARR 2006 means a contract of sale under which the seller transfers or agrees to transfer the property in the artwork to the buyer for a money consideration, which is the price. The sale can be conditional or absolute.

To qualify, the resale must be by a buyer or seller or (if the sale takes place through an agent) an agent acting in the course of a business of dealing in works of art (ARR 2006, reg 12(3)(a)). The sale price of the artwork must also be no less than 1,00o EUR (ARR 2006, reg $12(3)(b))$.

The sale will not qualify as a resale or trigger the royalty where, as we have seen above, the sale is a first sale by the artist or where (i) the seller acquired the artwork from the artist less than three years ago and (ii) the sale price is 10,000 EUR or less (ARR 2006, reg 12(4)). This provision is designed to ensure that where a dealer buys an artwork for 10,00o EUR or less direct from the artist for the purposes of resale, the dealer is not charged the artist's resale right on an onward sale to a customer within a reasonable period thereafter. However, where the dealer is unable to resell the artwork within the three year window and resells it thereafter, then the royalty will apply to the resale.

\subsubsection{How much is payable?}

The royalty is calculated as a percentage amount of the sale price, net of tax, but at the time of writing is capped so that the total amount of royalty payable on the sale of the artwork does not exceed 12,500 EUR.

The royalty is payable if the sale price of the artwork, net of tax, exceeds the pound sterling equivalent of 1,000 EUR. The royalty is calculated on a sliding scale.
$4 \%^{22}$
Up to 50,00o EUR
$3 \%$
Between 50,000.01 and 200,000 EUR
$1 \%$
Between 200,000.01 and 350,000 EUR
$0.5 \%$
Between 350,000.01 and 500,000 EUR
$0.25 \%$
In excess of 500,000 EUR

22 Member States are entitled to charge up to $5 \%$ for sales up to 50,00o EUR if they so choose. The United Kingdom has opted to charge $4 \%$. 
The scale is cumulative so that the different percentages apply to each part of the sale price. For example, a work sold for 400,00o EUR will be charged at $4 \%$ on the first 50,000 EUR, $3 \%$ on the next 150,000 EUR, $1 \%$ on the next 150,000 EUR and $0.5 \%$ on the balance of 50,000 EUR. However, the total royalty will be capped at 12,500 EUR. No VAT is payable on the artist's resale royalty.

\subsubsection{Who is entitled to the artist's resale royalty?}

The artist is entitled to the royalty; following the death of the artist, the artist's entitlement passes to the artist's estate or successors in title (ARR 2006, reg 9). The royalty is payable for each sale as long as the artwork remains in copyright, which is usually the lifetime of the artist plus 70 years.

As we have seen, to qualify, the artist must be either (i) a national of a European Economic Area (EEA) country or (ii) a national of a state outside the EEA which permits resale right protection for authors from EEA states and their successors in title (ARR 2006, reg 10(3)).

The person whose name appears on the artwork is presumed to be the author of the work unless the contrary is proved (ARR 2006, reg 6(1)).

The right to the resale royalty cannot be shared by the artist with anyone else (ARR 2006 reg 8(1)), or assigned to anyone (ARR 2006, reg 7 ). However, where the artwork is a work of joint ownership, the resale right belongs to the joint owners in common - held in equal shares or such shares as shall be agreed between them in writing (ARR 2006, reg 5).

Unusually, the resale right cannot be waived by the artist. A purported waiver of the right is deemed under reg 8 of ARR 2006 to be void.

\subsubsection{The right to information}

Any person entitled to the royalty, or their representative, has a right to such information as may be required to exercise the right. So an artist may require a dealer who has concluded a sale of one of the artist's works to disclose to the artist the sale price of the work. The person to whom the request is addressed is required do everything within his power to supply the information within 90 days of the receipt of the request. If not, the person making the request may apply to the county 
court for an order compelling the person to whom the request is made to provide the information.

\subsubsection{Liability to pay the royalty}

Regulation 13 of the ARR 2006 provides that the following persons shall be jointly and severally liable to pay the resale royalty:

(a) the seller; and

(b) one of the following:

(i) the seller's agent; or

(ii) if the seller does not have an agent, the buyer's agent; or

(iii) where there are no agents the buyer.

In other words, any and/or all of the above can be pursued by the artist for payment, either in full or in part, of the resale royalty.

There is a great deal of competition among auction houses to win major consignments from sellers. Auction houses have recognised that if the economic burden of the artist's resale royalty rests with the seller, then sellers of these consignments will be reluctant to sell works in countries where the artist's resale right applies. To address this concern they have therefore often adopted the practice of contractually shifting the financial burden onto the buyer. They have done this by charging buyers of qualifying artworks an additional sum equal to the amount of the artist's resale royalty. The auction house then remits that sum to the collecting society and the seller therefore receives no less in sale proceeds than he would have received had he sold his works in a non-EEA country. In the United Kingdom such an arrangement is permitted due to the overriding freedom of parties to contract and because there is nothing in the ARR 2006 which prevents it. The system was however challenged in France and has been the subject of a ruling from the European Court of Justice, which upheld the right under European law of auction houses to shift the contractual burden onto the buyer. In 2018 the French Cour de Cassation confirmed that view.

\subsubsection{When is the royalty payable?}

The royalty is payable on the completion of the sale. Anyone from whom the royalty is being demanded is entitled to withhold payment until evidence of entitlement to payment of the royalty is produced (ARR 2006, reg 12(2)). 


\subsubsection{Collection of the royalty}

The artist cannot collect the resale royalty. That right may be exercised only through a collecting society (ARR 2006, reg 14) such as the Design and Artist's Copyright Society (DACS) and the Artist's Collecting Society (ACS) on the artist's behalf. The law also ensures that even where the artist has not appointed a collecting society to act on the artist's behalf, the collecting society is nevertheless deemed to be appointed to collect the royalty. This gives rise to an unusual situation where a collecting society which has never been asked by an artist to represent him is entitled to collect royalties on his behalf.

\subsubsection{Problems with the artist's resale royalty}

The principal difficulty with the artist's resale royalty is that it operates as a disincentive to sell qualifying artworks in the countries in which it is applied. A seller who does not wish to pay the artist's resale royalty can opt to sell in one of the many countries outside of the EEA that do not apply the artist's resale royalty. London, Paris and Berlin are therefore less attractive to sellers of qualifying artworks than other major venues such as the United States, Hong Kong and Switzerland, all of whom do not require payment of a royalty to the artist. The incentive to sell outside the EEA is even greater where the seller is selling a high value collection, where each work could trigger a 12,500 EUR royalty payment.

There are also legitimate questions to be asked about whether the artist's resale royalty has achieved its aim of benefiting poorer artists. Because the higher royalties are paid to the most established artists, the main beneficiaries of the artist's resale right have been wealthy artists and the large and wealthy artist's estates, such as the Picasso estate.

Difficulties also arise from the fact that it is is triggered in full every time the work is resold. If a dealer purchases a high value qualifying work for resale then the resale right - which could be as high as 12,500 EUR - is payable. If the dealer sells it on to a buyer a week later, the full resale royalty is payable a second time. It could be argued that a more equitable way of dealing with this issue would be to charge the royalty as a percentage of the profit made on each transaction.

The dealer who purchases qualifying artworks direct from the artist to resell to the public can also run into problems if he does not sell the 
works on promptly. While any resale within three years will not trigger the resale royalty, a sale after that time will do so.

It is also difficult to police. Private art sale transactions usually take place discreetly and out of the public view. Responsible art market players will account for transactions where the royalty falls due but there is a concern that an unscrupulous seller or agent could evade the royalty by simply not accounting for the transaction.

Because of these difficulties it is fair to say that, while broadly popular with collecting societies and many artists, the artist's resale right has been controversial in the United Kingdom art market. It will be interesting to see whether the advent of Brexit will lead to the United Kingdom either adapting or revoking the artist's resale right.

\subsection{Royalties and enforcement}

\subsubsection{Introduction}

As we have seen, copyright law empowers the owner of the copyright - usually the artist or the artist's estate - to control or prohibit certain acts in relation to their copyright works. How the artist makes use of that power is a matter for the artist. They may either refuse to grant permission or grant permission subject to certain conditions, such as payment of royalties.

\subsubsection{Royalties}

While it is open to an artist not to consent to reproduction or distribution, most artists are happy to consent to the use of images of their works provided that it is done within certain parameters and provided that the artist is remunerated in the form of a royalty. The amount of the royalty and the terms of the use are a matter for negotiation in each case. Considering such requests, negotiating royalties and chasing payment is, however, an administrative burden, which many artists prefer to leave to collection agencies such as DACS.

The way in which this works is that the copyright owner will register with the collecting agency and enter into an agreement under which the agency is appointed on the copyright holder's behalf to administer the collection of royalties. The agency then regularly accounts to the 
copyright holder for any royalties collected. The agency will charge a fee for this service - usually around $20 \%$ of the royalties collected.

This centralisation of the approval and payment process is also helpful for those who are seeking consent for the use or reproduction of copyright images. Through the DACS website they can establish whether or not the copyright owner is represented by the collecting agency, and, if he or she is represented, seek consent from the agency.

\subsubsection{Enforcement}

Copyright in an artwork protected by copyright is infringed where it is reproduced or distributed without the permission of the copyright owner. Where this occurs the copyright owner will usually want to either prevent the infringement or obtain compensation for the unauthorised use.

Most such cases can be resolved by negotiation and without the need for court proceedings. However, where this is not possible the copyright holder may need to look to legal action for redress. The courts have wide powers to enforce a copyright holder's rights. These include an injunction to prevent an imminent or continuing infringement, the award of damages or an order for delivery up of infringing materials.

\subsubsection{Damages}

The calculation of damages may be based upon the royalties which the copyright owner would have received had the infringer obtained consent for the infringing act. However, damages awards may also take account of other factors, such as the profits made by the infringer through the infringement or the financial or moral prejudice caused to the copyright owner through the infringement. In cases where the infringement is deliberate, s 97(2) of the CDPA 1988 also gives the court the ability to award additional damages for flagrant copyright infringement.

\subsubsection{Injunctions}

An injunction may be appropriate in cases where urgent action is needed to prevent an imminent infringement or the continuation of an existing infringement. A prohibitory injunction is an order issued by the court restraining a person from carrying out or continuing to 
carry out an act which infringes or may infringe the rights of another person. A mandatory injunction is a court order compelling a person to carry out a certain act, for example, to deliver up infringing copies of an artwork. Failure to comply with an injunction can have very serious consequences, including imprisonment. Injunctions are usually temporary measures, designed to preserve the status quo pending a hearing or trial of the issues. In most cases applications for injunctions are therefore made before legal proceedings have begun. In some cases the hearing will be inter partes, involving both the applicant and the defendant making submissions to the judge. However, in urgent cases the court will hear an application for an injunction on an ex parte basis. This means that the judge will make a decision based upon the submissions of the applicant only. In such cases, if the injunction is granted it will be served upon the defendant, who will then at a later date have an opportunity to make submissions to the court to get the injunction set aside or amended. If the defendant is unsuccessful the injunction will remain in place until the trial has taken place and the court has given judgment in the case. Injunctions are often considered to be the nuclear option of enforcement. This is because the grant of an injunction can have a devastating effect upon the party subject to the injunction, regardless of the outcome of the trial. The risks for the applicant are also very high. Injunction applications are extremely expensive and the applicant can risk having to pay his own costs and those of the defendant if he or she loses at trial. The courts are therefore extremely careful to ensure that injunctions are granted only in cases where it is just and equitable to do so. Applicants for injunctions are also required to give undertakings, known as 'cross-undertakings in damages', to the court that in the event that the injunction turns out to have been incorrectly granted, the applicant will compensate the defendant for any loss suffered as a consequence of the injunction. The applicant will also be required to demonstrate that he or she has the financial means to honour that undertaking if called upon to do so.

The application for an injunction must be made with supporting evidence, setting out all the evidence on which the applicant relies. Where the application is made on an ex parte basis or on short notice there is an obligation to give full and frank disclosure including any material facts which do not support the applicant's case.

Applications for injunctions must be made without delay. Once the applicant becomes aware of the actual or threatened infringement he or she must act immediately by applying for an injunction. A delay in 
doing so will usually be fatal to the application. Certain requirements also need to be in place in order for the court to grant an injunction. ${ }^{23}$ First, the court must be satisfied that there is a serious issue to be tried. In a copyright infringement case the applicant will need to demonstrate that an infringing act has been or is about to be committed, and that he or she has not consented to it. Second, the court will consider whether, if the injunction were not to be granted, an award of damages would adequately compensate the applicant in the event of an infringement. For instance, in a case where the copyright owner would, had he or she been approached in the first place, have licensed the reproduction of his artwork in return for a fee, the court will consider whether payment of damages equal to or greater than the royalty fee might be an adequate remedy, rather than an injunction. The answer in that case may be different to a case where an artist's work is being used in a context which he would not have consented to at any price. In such a case damages may not be an adequate remedy for an infringement. Third, the court will consider the balance of convenience. This involves taking a step back in order to determine whether the grant of an injunction is likely to unduly destabilise the affairs of one or the other party. Finally, the court can consider whether or not to take account of any special factors which are particular to the case.

It will be apparent from the tests above that the courts are extremely cautious about the grant of injunctions, and tend to prefer the option of a speedy trial where that is possible. From an applicant's point of view such applications are also fraught with risk. An unsuccessful application, or a successful application which is then followed by an unsuccessful claim at trial, can result in a very heavy financial costs burden.

\subsubsection{Website blocking orders}

The ease with which copyright can be infringed using the internet presents particular enforcement challenges for copyright owners. It is often difficult to identify and locate the owners of websites containing infringing material, let alone take enforcement action against them. As a result, many copyright owners seek to enforce their rights via the internet service provider (ISP) hosting the infringing site. The reason for this is that ISPs are easier to identify, and often within the jurisdiction of the copyright holder. While the ISP will usually not be liable for

23 American Cyanamid Co. v Ethicon Ltd [1975] 1 All ER 504. 
copyright infringement by third party websites which it hosts, it does have the power to block the website.

The ability of a UK court to order the ISP to block websites is to be found in s 97A of the CDPA 1988. For an application to the court for a blocking order to be successful, the following requirements must be met: ${ }^{24}$

- the defendant must be an ISP;

- the website in question must be infringing the claimant's copyright;

- the users or operators of the website must be making use of the ISP's services in order to infringe copyright;

- the ISP must be aware of another person using their platform or services to infringe copyright.

\subsection{Graffiti art}

The general public often consider graffiti a form of antisocial behaviour. However, the success of artists such as Banksy has led to graffiti art becoming more sophisticated and evolving into a recognised art form. To the extent that graffiti art is controversial, the controversy centres not so much upon the art as on the damage to the buildings and structures to which it is applied. Graffiti artists need to be aware of the law in this regard.

The principal piece of legislation used relating to graffiti is $\mathrm{s} 1$ of the Criminal Damage Act 1971. This Act provides that a person who without lawful excuse destroys or damages any property belonging to another, intending to destroy or damage any such property or being reckless as to whether any such property would be destroyed or damaged, is guilty of an offence.

The Criminal Damage Act 1971 provides for a fine of up to $£ 5,000$ or a community service order where the damage caused by the graffiti is $£ 5,000$ or less. The community service order is used principally in relation to young offenders. Where the damage caused exceeds $£ 5$,ooo

24. Twentieth Century Fox Film Corp v British Telecommunications (Newzbin2) 2011 All ER (D) 275. 
the case will be referred for trial to the Crown Court, which has more extensive sentencing powers, including imprisonment.

Whether or not an offence has been committed will depend upon the attitude of the owner of the property to which the graffiti has been applied. If the owner consented to the graffiti or does not regard it as being damage, no offence will have been committed. It is also a defence for a person charged with an offence under the Criminal Damage Act 1971 to argue that at the time of applying the graffiti he or she believed that the owner of the damaged property had consented to application of the graffiti, or would have so consented to it if he or they had known of it.

Police investigating criminal damage caused by graffiti art are also entitled, under the Criminal Damage Act 1971, to obtain a warrant to search a suspect's home and computer records in order to find evidence. It is also an offence under s 3 of the Criminal Damage Act 1971 to be found in possession of anything - which would include spray cans - with intent to destroy or damage property. However, there are no stop and search powers under the Criminal Damage Act 1971.

In addition to the Criminal Damage Act 1971, the Clean Neighbourhoods and Environment Act 2005 gives local authorities the power to issue a fixed penalty notice - usually $£ 75$ - for anyone caught applying graffiti. Provided the fixed penalty is paid within 14 days, no criminal proceedings can be brought against the person to whom the notice has been issued. The Clean Neighbourhoods and Environment Act 2005 also makes it illegal for retailers to sell spray paint to people under the age of 16 . It is a defence for the retailer to prove that he or she took reasonable steps to confirm the age of the person buying it.

While graffiti is usually controversial due to the damage it causes, the content of the artwork can, as with any artwork, also be problematic. Arguably, the fact that graffiti is usually prominently and publicly displayed makes it even more exposed to charges where it uses images or words which incite racial hatred or religious hatred. Such images and works can amount to an offence under the Public Order Act 1986 and the Racial and Religious Hatred Act 2006 (see section 10.5.3, 'Art, religion and race').

The question of ownership of graffiti art also arises where it is applied to an object or building belonging to a third party. This issue was 
addressed in the case of Creative Foundation v Dreamland Leisure. ${ }^{25}$ In 2014 the artist Banksy had applied graffiti to the wall of a building owned by a landlord, Stonefield Estates Ltd. Recognising that graffiti works by Banksy commanded significant prices in the art market, the tenant, Dreamland Leisure, removed the wall with the graffiti and sought to put it up for sale. It did so relying on a clause in its lease requiring it to remove or paint over graffiti. The court held that, notwithstanding the obligation to repair, the ownership in the wall - and therefore the artwork on it - remained with the landlord.

While this case dealt primarily with the question of ownership of the wall and the artwork, there is also the question of who owns the intellectual property rights in the artwork. Although this was not the primary issue in the Creative Foundation case, the judge confirmed obiter that copyright remains with the artist. The result is that graffiti has a double ownership structure. The building owner is the owner of the graffiti artist's 'canvas' whereas the image rights remain with the graffiti artist. This raises the interesting question of whether the artist can object to the sale of the work by the building owner. The likely answer is that he or she cannot, provided his or her moral rights are not infringed (see section 1.2.2, 'Moral rights'). However, he or she will in principle be entitled to artist's resale royalty on any resale and, as the owner of the copyright in the image, will be entitled to control over copying and reproductions of the artwork.

25 [2015] EWHC 2556. 